\title{
Assessing Turnover Time, Communication and Report Quality among Histopathologists and Their Clients.
}

Assessing Turnover, Communication and Report Quality

\section{Dr. Waleed A. AlRajban', Dr. Khaldoon A. AlJerian², Dr. Zainab Z. AlZaher ${ }^{3}$, Dr. Wijdan M. AlEithan ${ }^{4}$, Dr. Lujain H. AlAmoudi ${ }^{5}$}

${ }^{1}$ Pathology Dept. from King Khalid University Hospital in Riyadh.

${ }^{2}$ Pathology Dept. College of Medicine, King Saud University in Riyadh

${ }^{3}$ Pathology Dept. from King Fahad University Hospital in Khobar.

${ }^{4}$ Medical Intern from Alfarabi medical college in Riyadh. ${ }^{5}$ Medical Intern from King Abdulaziz University Hospital, Jeddah, Saudi Arabian.

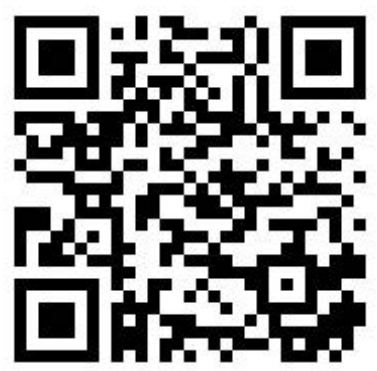

Abstract:

Numerous studies have been published assessing physicians' satisfaction regarding the quality of pathology departments, which have led to further enhancement.

Our objective is to estimate the satisfaction level between histopathologists and healthcare providers in Saudi Arabia in terms of turnover time in histopathology laboratories and communication, that is, quality of reporting between the two groups.

In this cross-sectional study, we developed a questionnaire covering the areas identified in the literature regarding evaluating the satisfaction between histopathologists and their clients. The questionnaire was conducted in 5 hospitals in Saudi Arabia, each of which has its histopathology unit accredited by the College of American Pathologists.

In our study, we report the results of 129 clients and 30 histopathologists.

On the satisfaction scale ( 1 out 5 , where is $1=$ very unsatisfied and $5=$ very satisfied), the clients reported medians of $3.40,3.83$, and 4.00 for turnover time, communication with histopathologists, and quality of reports. Histopathologists reported medians of 4.00, 4.41, and 4.16 for turnover time, communication with their clients, and request style and its sufficiency.

Our conclusion is there is an inclination toward satisfactory results in the examined categories between the histopathologists and their clients.

\section{Keywords:}

Report, Turnover time, Communication, Histopathology, Quality. 


\section{Introduction:}

Given the growing population in Saudi Arabia, there is likely to be an increased burden on the health care system and physicians. Pathology departments play a significant role in diagnosing patients or aiding with critical information guiding clinicians to the proper management of either inpatient or outpatient sets. The quality of pathology department services toward their clients is no less important than that of clinicians toward their patients.

Numerous papers have been published in many countries assessing pathology department's quality in general, and specifically, histopathology. The current study focuses on histopathology quality is because it still the gold standard diagnostic method and in the intervention and planning for proper management. Nonetheless, these diagnoses depend entirely on humans, from providing adequate clinical information up to the sign off of reports. Therefore, these procedures are prone to human error. Moreover, demands on histopathology employees have increased due to an increase in population, ongoing development of guidelines, which necessitate further modification of reports, the process of sectioning and staining, and hence, the management. ${ }^{(1,2)}$ This all give the importance of assessing histopathology units to place more improvement, detecting the dissatisfaction areas and errors, or do both.

Furthermore, assessing customers' satisfaction regarding a service is vital for further development of delivering that service, ensuring customer satisfaction and, in our case, providing better healthcare for the community.

The literature reveals aspects of dissatisfaction in terms of communication, expectations, providing sufficient information about patients, quality of histopathological reports, and turnover time. ${ }^{(3,4)}$ However, continuous assessment and establishing an approach for development of the system or embedding proper education has shown to be effective. ${ }^{(5-7)}$ Since improving the health care system and enhancing patient care is of utmost importance, we must first identify areas that require and permit further improvement or modification, which is the purpose of this study.

\section{Methodology:}

This is a quantitative, cross-sectional study, conducted in three major cities in Saudi Arabia: Riyadh, Jeddah, and Khobar. A total of 7 tertiary centers were selected as their pathology departments are accredited by the College of American Pathologists (CAP). CAP has standardized requirements, which will provide an approximate estimation of where the defects are once they are observed.

We developed a questionnaire (see Appendix) covering the areas we identified in the literature regarding communication among physicians and healthcare providers, the assessment of the satisfaction of the sufficiency and style of pathology reports from both, report turnover time, and the requests made by physicians.

The questionnaire was divided into three parts. Part one focused on the major idea of this study; it contains three categories evaluating time, communication, and the style of the report and its sufficiency. Satisfaction was measured on a 5point Likert scale, where $1=$ Very unsatisfied and $5=$ Very satisfied.

The second part focused on the rate of discrepancies and errors in histopathology laboratories, while the third part focused on the expectations, the reason for requesting a second opinion and inquiries about histopathologists' reports, and further attempts to identify the reason behind dissatisfaction.

The questionnaires then were given to trained and supervised data collectors.

The centers that participated in this study are King Khalid University Hospital, King Abdulaziz University Hospital, and King Fahad Medical City in Riyadh, King Abdulaziz University Hospital in Jeddah, and King Fahad University Hospital in Khobar. Unfortunately, two other hospitals were excluded due to lack of response.

In each of these centers, verbal consent was obtained either from the pathology department in a designated hospital or from the institutional review board (IRB). The data gathered in any of these facilities is classified. Questionnaires were distributed to histopathologists and their clients. We specified that the surveys would only be distributed to consultants, with exclusion of those who have worked at the hospital for less than a year, and those specialties that rarely request a histopathological report (e.g., Anesthesiology).

\section{Corresponding Author:}

Dr. Waleed Abdullah Al Rajban

King Saud University and King Khalid University Pathology Department

Email:waleed.alrajban@gmail.com 
A sample size of at least 30 consultants (client) from each hospital, calculated proportionately from "Physician Satisfaction with Clinical Laboratory Services." (8)

Since there is no known similar study that has surveyed histopathologists, and given the low number of consultant histopathologists in Saudi Arabia, it is a reasonable approach to obtain data from all the consultants from histopathology units.

Sampling and questionnaire distribution was conducted randomly based on who will be attending at the time and day of data collection.

After reviewing the consent form and ensuring the confidentiality, participants were given a questionnaire, and to ensure a high level of response, the data collector was present at the time of completing the questionnaire.

Two forms of the surveys were distributed: one for the consultants from the various departments in the hospital, focusing on surgical ones, and the other for consultant histopathologists.

From April until June, data collectors were able to gather data from 129 clients and 30 histopathologists.
During the data collection, each data collector was given instructions and a sheet with definitions (See Appendix.)

SPSS v. 22 was used to analyze the data. Statistical analysis was used to calculate the frequencies and the interquartile range for it is a better measurement tool for Likert scale of satisfaction, with confidence interval of $95 \%$.

\section{Results:}

We report the results of 129 clients from multiple departments (general surgery $=31$, orthopedics $=$ 12 , neurosurgery $=12$, obstetrics and gynecology $=12$, internal medicine $=10$, pediatrics $=10$, urology $=9$, hematology and oncology $=9$, ear, nose, and throat surgery $=8$, pulmonology $=6$, hepatobiliary and transplant $=4$, gastroenterology $=3$, neurology $=2$, and rheumatology $=1$ ), and of 30 histopathologists from 5 different hospitals.

We analyzed each item in the questionnaire for both histopathologists and their clients (See Tables 1-3).

\section{Table 1}

\begin{tabular}{|c|c|c|c|c|c|c|c|}
\hline & & & \% RTTT ${ }^{*}$ & \% ETTT $^{\dagger}$ & \%ISTTT & \%OSTTT ${ }^{\S}$ & $\begin{array}{c}\text { \%Overall } \\
\text { Time*** }\end{array}$ \\
\hline \multirow{6}{*}{$\begin{array}{c}\text { Clients } \\
\text { (Physicia } \\
\text { ns) }\end{array}$} & \multirow[t]{6}{*}{ Valid } & $\begin{array}{c}\text { Very } \\
\text { unsatisfied }\end{array}$ & 6.2 & 10.9 & 4.7 & 7.0 & 7.8 \\
\hline & & Unsatisfied & 10.1 & 8.5 & 10.1 & 11.6 & 10.9 \\
\hline & & Neutral & 27.9 & 37.2 & 25.6 & 35.7 & 28.7 \\
\hline & & Satisfied & 40.3 & 34.1 & 37.2 & 33.3 & 40.3 \\
\hline & & $\begin{array}{c}\text { Very } \\
\text { satisfied }\end{array}$ & 15.5 & 9.3 & 22.5 & 12.4 & 12.4 \\
\hline & & Total & 100.0 & 100.0 & 100.0 & 100.0 & 100.0 \\
\hline \multirow[t]{6}{*}{$\begin{array}{c}\text { Histopath } \\
\text { ologists }\end{array}$} & \multirow[t]{6}{*}{ Valid } & $\begin{array}{c}\text { Very } \\
\text { unsatisfied }\end{array}$ & 0 & 0 & 0 & 0 & 0 \\
\hline & & Unsatisfied & 0 & 6.7 & 3.3 & 3.3 & 0 \\
\hline & & Neutral & 20.0 & 36.7 & 20.0 & 26.7 & 23.3 \\
\hline & & Satisfied & 53.3 & 46.7 & 46.7 & 43.3 & 56.7 \\
\hline & & $\begin{array}{c}\text { Very } \\
\text { satisfied }\end{array}$ & 26.7 & 10.0 & 30.0 & 26.7 & 20.0 \\
\hline & & Total & 100.0 & 100.0 & 100.0 & 100.0 & 100.0 \\
\hline
\end{tabular}

Category 1: Satisfaction with the time in histopathology lab.

RTTT*: Routine Test Turnover Time.

ETTT $^{\dagger}$ : Esoteric Test Turnover Time.

ISTTT*: Inpatient Test Turnover Time.

OSTTT $^{\S}$ : Outpatient Test Turnover Time.

Overall Time ${ }^{* *}$ : Client satisfaction with the general timeliness. 
Assessing Turnover, Communication and Report Quality

Table 2 Category 2: Satisfaction with communication between histopathologists and their clients.

\begin{tabular}{|c|c|c|c|c|c|c|c|c|}
\hline & & & $\begin{array}{l}\text { \%Critical } \\
\text { Value } \\
\text { Notificati } \\
\text { on }\end{array}$ & $\begin{array}{l}\text { \%Accessibi } \\
\text { lity to } \\
\text { pathologist/ } \\
\text { physician }\end{array}$ & $\begin{array}{l}\text { \%Accessibi } \\
\text { lity to lab } \\
\text { manager }\end{array}$ & $\begin{array}{l}\text { \%Accessibi } \\
\text { lity to lab } \\
\text { staff }\end{array}$ & $\begin{array}{c}\text { \%Lab } \\
\text { managemen } \\
\mathrm{t} \\
\text { Responsive } \\
\text { ness }\end{array}$ & $\begin{array}{l}\text { \% Intraopera } \\
\text { tive } \\
\text { Consultation }\end{array}$ \\
\hline \multirow[t]{6}{*}{$\begin{array}{c}\text { Clients } \\
\text { (Physicians) }\end{array}$} & \multirow[t]{6}{*}{ Valid } & $\begin{array}{c}\text { Very } \\
\text { unsatisfie } \\
\text { d } \\
\end{array}$ & 3.9 & 7.0 & 4.7 & 5.4 & 3.1 & 4.7 \\
\hline & & $\begin{array}{c}\text { Unsatisfi } \\
\text { ed }\end{array}$ & 10.1 & 10.9 & 7.8 & 6.2 & 9.3 & 5.4 \\
\hline & & Neutral & 15.5 & 16.3 & 32.6 & 21.7 & 28.7 & 33.3 \\
\hline & & Satisfied & 27.1 & 34.1 & 32.6 & 39.5 & 34.9 & 31.8 \\
\hline & & $\begin{array}{c}\text { Very } \\
\text { satisfied }\end{array}$ & 43.4 & 31.8 & 22.5 & 27.1 & 24.0 & 24.8 \\
\hline & & Total & 100.0 & 100.0 & 100.0 & 100.0 & 100.0 & 100.0 \\
\hline \multirow[t]{6}{*}{$\begin{array}{l}\text { Histopatholo } \\
\text { gists }\end{array}$} & \multirow[t]{6}{*}{ Valid } & $\begin{array}{c}\text { Very } \\
\text { unsatisfi } \\
\text { ed } \\
\end{array}$ & 0 & 6.7 & 0 & 0 & 0 & 0 \\
\hline & & $\begin{array}{c}\text { Unsatisfi } \\
\text { ed }\end{array}$ & 3.3 & 6.7 & 0 & 3.3 & 0 & 3.3 \\
\hline & & Neutral & 23.3 & 26.7 & 6.7 & 3.3 & 16.7 & 6.7 \\
\hline & & Satisfied & 23.3 & 33.3 & 20.0 & 10.0 & 43.3 & 30.0 \\
\hline & & $\begin{array}{c}\text { Very } \\
\text { satisfied }\end{array}$ & 50.0 & 26.7 & 73.3 & 83.3 & 40.0 & 60.0 \\
\hline & & Total & 100.0 & 100.0 & 100.0 & 100.0 & 100.0 & 100.0 \\
\hline
\end{tabular}

Table 3 Category 3: Satisfaction with the report's style and content between histopathologists and their clients.

\begin{tabular}{|c|c|c|c|c|c|c|c|c|}
\hline & & & $\begin{array}{l}\text { \% Typogr } \\
\text { aphical } \\
\text { Errors }\end{array}$ & $\begin{array}{l}\text { \%Report } \\
\text { Accuracy }\end{array}$ & $\begin{array}{l}\text { \%Content } \\
\text { Sufficienc } \\
\text { y }\end{array}$ & $\begin{array}{l}\text { \%Underst } \\
\text { andable } \\
\text { Report }\end{array}$ & $\begin{array}{l}\text { Re } \\
\text { port } \\
\text { Style }\end{array}$ & $\begin{array}{l}\% \text { Ove } \\
\text { rall } \\
\text { Style* }\end{array}$ \\
\hline \multirow[t]{6}{*}{$\begin{array}{l}\text { Clients } \\
\text { (Physicians) }\end{array}$} & \multirow[t]{6}{*}{ Valid } & $\begin{array}{l}\text { Very } \\
\text { unsatisfied }\end{array}$ & 3.9 & 3.9 & 5.4 & 3.1 & 3.9 & 3.9 \\
\hline & & Unsatisfied & 11.6 & 7.8 & 6.2 & 4.7 & 5.4 & 6.2 \\
\hline & & Neutral & 22.5 & 14.0 & 17.8 & 18.6 & 27.9 & 20.9 \\
\hline & & Satisfied & 31.8 & 41.9 & 41.1 & 39.5 & 35.7 & 50.4 \\
\hline & & $\begin{array}{l}\text { Very } \\
\text { satisfied }\end{array}$ & 30.2 & 32.6 & 29.5 & 34.1 & 27.1 & 18.6 \\
\hline & & Total & 100.0 & 100.0 & 100.0 & 100.0 & 100.0 & 100.0 \\
\hline \multirow[t]{6}{*}{$\begin{array}{l}\text { Histopatholog } \\
\text { ists }\end{array}$} & \multirow[t]{6}{*}{ Valid } & $\begin{array}{l}\text { Very } \\
\text { unsatisfied }\end{array}$ & 6.7 & 0 & 0 & 0 & 0 & 0 \\
\hline & & Unsatisfied & 3.3 & 0 & 0 & 0 & 0 & 0 \\
\hline & & Neutral & 20.0 & 10.0 & 10.0 & 10.0 & 16.7 & 13.3 \\
\hline & & Satisfied & 46.7 & 50.0 & 53.3 & 43.3 & 40.0 & 56.7 \\
\hline & & $\begin{array}{l}\text { Very } \\
\text { satisfied }\end{array}$ & 23.3 & 40.0 & 36.7 & 46.7 & 43.3 & 30.0 \\
\hline & & Total & 100.0 & 100.0 & 100.0 & 100.0 & 100.0 & 100.0 \\
\hline
\end{tabular}

Overall Style*: Client satisfaction with the general style.

We then merged the mean of each respondent to obtain the overall satisfaction for each of the three categories (see Tables 4, 5).

In terms of turnover time, the median satisfaction for clients (Table 4) was 3.40, with a 95\% confidence interval $(\mathrm{CI})(3.25,3.57)$, and the interquartile range was 1.0 . 
Table 4

\section{Clients' Overall Satisfaction}

\begin{tabular}{|c|c|c|c|c|}
\hline & & & Statistic & $\begin{array}{l}\text { Std. } \\
\text { Error }\end{array}$ \\
\hline \multirow{9}{*}{$\begin{array}{l}\text { Overall Time Satisfaction of Histopathology } \\
\text { Lab }\end{array}$} & \multicolumn{2}{|l|}{ Mean } & 3.41 & .082 \\
\hline & \multirow[t]{2}{*}{$\begin{array}{l}95 \% \text { Confidence Interval } \\
\text { for Mean }\end{array}$} & $\begin{array}{l}\text { Lower } \\
\text { Bound }\end{array}$ & 3.25 & \\
\hline & & $\begin{array}{l}\text { Upper } \\
\text { Bound }\end{array}$ & 3.57 & \\
\hline & \multicolumn{2}{|l|}{ Median } & 3.40 & \\
\hline & \multicolumn{2}{|l|}{ Variance } & .874 & \\
\hline & \multicolumn{2}{|l|}{ Std. Deviation } & .935 & \\
\hline & \multicolumn{2}{|l|}{ Range } & 4 & \\
\hline & \multicolumn{2}{|l|}{ Interquartile Range } & 1 & \\
\hline & \multicolumn{2}{|l|}{ Skewness } & -.680 & .213 \\
\hline \multirow{9}{*}{$\begin{array}{l}\text { Overall Communication Satisfaction with } \\
\text { Histopathologists }\end{array}$} & \multicolumn{2}{|l|}{ Mean } & 3.73 & .074 \\
\hline & \multirow[t]{2}{*}{$\begin{array}{l}95 \% \text { Confidence Interval } \\
\text { for Mean }\end{array}$} & $\begin{array}{l}\text { Lower } \\
\text { Bound }\end{array}$ & 3.59 & \\
\hline & & $\begin{array}{l}\text { Upper } \\
\text { Bound }\end{array}$ & 3.88 & \\
\hline & \multicolumn{2}{|l|}{ Median } & 3.83 & \\
\hline & \multicolumn{2}{|l|}{ Variance } & .705 & \\
\hline & \multicolumn{2}{|l|}{ Std. Deviation } & .839 & \\
\hline & \multicolumn{2}{|l|}{ Range } & 4 & \\
\hline & \multicolumn{2}{|l|}{ Interquartile Range } & 1 & \\
\hline & \multicolumn{2}{|l|}{ Skewness } & -.685 & .213 \\
\hline \multirow[t]{9}{*}{ Overall Histopathology Report Satisfaction } & \multicolumn{2}{|l|}{ Mean } & 3.82 & .076 \\
\hline & \multirow[t]{2}{*}{$\begin{array}{l}95 \% \text { Confidence Interval } \\
\text { for Mean }\end{array}$} & $\begin{array}{l}\text { Lower } \\
\text { Bound }\end{array}$ & 3.67 & \\
\hline & & $\begin{array}{l}\text { Upper } \\
\text { Bound }\end{array}$ & 3.98 & \\
\hline & \multicolumn{2}{|l|}{ Median } & 4.00 & \\
\hline & \multicolumn{2}{|l|}{ Variance } & .753 & \\
\hline & \multicolumn{2}{|l|}{ Std. Deviation } & .868 & \\
\hline & \multicolumn{2}{|l|}{ Range } & 4 & \\
\hline & \multicolumn{2}{|l|}{ Interquartile Range } & 1 & \\
\hline & \multicolumn{2}{|l|}{ Skewness } & -1.057 & .213 \\
\hline
\end{tabular}


Assessing Turnover, Communication and Report Quality

Table 5

Histopathologists' Overall Satisfaction

\begin{tabular}{|c|c|c|c|c|}
\hline \multirow{3}{*}{$\begin{array}{l} \\
\text { Overall Time Satisfaction of } \\
\text { Histopathology Lab }\end{array}$} & & & Statistic & Std. Error \\
\hline & \multicolumn{2}{|l|}{ Mean } & 3.9200 & .10085 \\
\hline & \multirow{2}{*}{$\begin{array}{l}\text { 95\% Confidence Interval for } \\
\text { Mean }\end{array}$} & Lower Bound & 3.7137 & \\
\hline & & Upper Bound & 4.1263 & \\
\hline & \multicolumn{2}{|l|}{ Median } & 4.0000 & \\
\hline & \multicolumn{2}{|l|}{ Variance } & .305 & \\
\hline & \multicolumn{2}{|l|}{ Std. Deviation } & .55236 & \\
\hline & \multicolumn{2}{|l|}{ Range } & 2.00 & \\
\hline & \multicolumn{2}{|l|}{ Interquartile Range } & .85 & \\
\hline & \multicolumn{2}{|l|}{ Skewness } & -.383 & .427 \\
\hline \multirow{9}{*}{$\begin{array}{l}\text { Overall Communication } \\
\text { Satisfaction with the clients }\end{array}$} & \multicolumn{2}{|l|}{ Mean } & 4.3278 & .07474 \\
\hline & \multirow{2}{*}{$\begin{array}{l}\text { 95\% Confidence Interval for } \\
\text { Mean }\end{array}$} & Lower Bound & 4.1749 & \\
\hline & & Upper Bound & 4.4806 & \\
\hline & \multicolumn{2}{|l|}{ Median } & 4.4167 & \\
\hline & \multicolumn{2}{|l|}{ Variance } & .168 & \\
\hline & \multicolumn{2}{|l|}{ Std. Deviation } & .40938 & \\
\hline & \multicolumn{2}{|l|}{ Range } & 1.50 & \\
\hline & \multicolumn{2}{|l|}{ Interquartile Range } & .38 & \\
\hline & \multicolumn{2}{|l|}{ Skewness } & -.452 & .427 \\
\hline \multirow{9}{*}{$\begin{array}{l}\text { Overall Satisfaction over } \\
\text { clients' order and requests }\end{array}$} & \multicolumn{2}{|l|}{ Mean } & 4.1889 & .11180 \\
\hline & \multirow{2}{*}{$\begin{array}{l}\text { 95\% Confidence Interval for } \\
\text { Mean }\end{array}$} & Lower Bound & 3.9602 & \\
\hline & & Upper Bound & 4.4175 & \\
\hline & \multicolumn{2}{|l|}{ Median } & 4.1667 & \\
\hline & \multicolumn{2}{|l|}{ Variance } & .375 & \\
\hline & \multicolumn{2}{|l|}{ Std. Deviation } & .61235 & \\
\hline & \multicolumn{2}{|l|}{ Range } & 2.00 & \\
\hline & \multicolumn{2}{|l|}{ Interquartile Range } & .75 & \\
\hline & \multicolumn{2}{|l|}{ Skewness } & -.413 & .427 \\
\hline
\end{tabular}

\section{A) Client Satisfaction:}

From the perspective of communication, clients were found to be more satisfied; a median of 3.83 with $95 \%$ CI $(3.59,3.89)$ and an interquartile range of 1.0.

Regarding the style of the report, clients' median was 4.00 , with $95 \%$ CI $(3.67,3.98)$, and an interquartile range of 1.0 .

In terms of requesting a second review or opinion (see Table 6), the participants indicated that they submit a request for another review when the diagnosis does not correlate with the clinical presentation in $54.3 \%$ of the cases, $36.4 \%$ due insufficient details in the report, $21.7 \%$ because a report was not understandable or lacked clarity, $2.3 \%$ due to misidentification of the case or the patient, and $2.3 \%$ did not make such a request. 


\begin{tabular}{|c|c|c|c|c|c|c|}
\hline \multicolumn{7}{|c|}{$\begin{array}{l}\text { Table } 6 \\
\text { Reason for requesting for a pathology report review or a second opinion }\end{array}$} \\
\hline & \multicolumn{3}{|c|}{ Clients (Physicians) } & \multicolumn{3}{|c|}{ Histopathologists } \\
\hline & \multicolumn{2}{|c|}{ Responses } & \multirow{2}{*}{$\begin{array}{l}\text { Percent } \\
\text { of } \\
\text { Cases }\end{array}$} & \multicolumn{2}{|c|}{ Responses } & \multirow{2}{*}{$\begin{array}{l}\text { Percent } \\
\text { of } \\
\text { Cases }\end{array}$} \\
\hline & $\mathrm{N}$ & Percent & & $\mathrm{N}$ & Percent & \\
\hline $\begin{array}{l}\text { The Diagnosis Does Not Correlate with The } \\
\text { Clinical Presentation }\end{array}$ & 70 & $46.4 \%$ & $54.3 \%$ & 21 & $60.0 \%$ & $70.0 \%$ \\
\hline Insufficient Details & 47 & $31.1 \%$ & $36.4 \%$ & 10 & $28.6 \%$ & $33.3 \%$ \\
\hline Non-understandable (Lack of Clarity) Report & 28 & $18.5 \%$ & $21.7 \%$ & 3 & $8.6 \%$ & $10.0 \%$ \\
\hline Misidentification of The Patient & 3 & $2.0 \%$ & $2.3 \%$ & 2 & $5.4 \%$ & $6.7 \%$ \\
\hline No Response ${ }^{*}$ & 3 & $2.0 \%$ & $2.3 \%$ & 1 & $2.7 \%$ & $3.3 \%$ \\
\hline
\end{tabular}

No Response*: A client had not made such a request before.

Regarding the standards and procedures of the histopathology units, $47.3 \%$ of the clients were somewhat familiar with the process immediately after ordering a test or biopsy, 38.0\% were completely familiar with the process, and $14.7 \%$ were not. Moreover, $45.7 \%$ of the participants indicated they have an estimate of the time required to deliver the final report about the ordered test, while $41.9 \%$ responded they know the time required for the report to be released, and $12.4 \%$ did not know.

\section{B) Histopathologist Satisfaction:}

On the other hand, histopathologists (Table 5) were satisfied with the turnover time of their laboratory and efforts to produce a histopathology report from the time of the request; median 4.00 with a $95 \%$ CI (3.71, 4.12) and an interquartile range of 0.85 .

In terms of the communication with their clients, histopathologists were satisfied, with a median of 4.41, with $95 \% \mathrm{CI}(4.17,4.48)$ and an interquartile range of 0.38 .

Regarding the style of the request submitted to them by their clients, histopathologists positively evaluated the style with a median 4.16 , with $95 \%$ CI $(3.96,4.41)$, while the interquartile range was 0.75 .

In terms of response regarding a second review of histopathological reports, $72.4 \%$ of the differential diagnoses, which were provided by a histopathologist, did not correlate with the histopathological diagnosis, $34.5 \%$ due to insufficient details in the report, followed by $10.3 \%$ for a non-understandable report, and $6.7 \%$ for misidentification of the patient.

Histopathologists were asked if the number of the employees in the histopathology unit was adequate to fulfill or meet the requirements of the load in the hospital. A total of $63.3 \%$ acknowledge that the number of the employees was sufficient, $16.6 \%$ thought there was a deficiency, and $20 \%$ were unsure.

When they were asked if the technicians in the unit were sufficiently trained to perform what is required when needed, the majority $(73.3 \%$ ) agreed, while the minority thought either they needed further training or were not efficiently trained (16.7\% and $10 \%)$.

\section{Discussion:}

There is variation in the results of studies assessing whether the information provided by clinicians was adequate when requesting histopathology reports In study conducted in the United States, Nakhleh ${ }^{(9)}$ showed that $6 \%$ of all surgical pathology specimens had deficiencies regarding identification and accessioning with "no clinical history or diagnosis present on the requisition slip" being the most common deficiency. A study 
conducted by Burton ${ }^{(10)}$ in the United Kingdom revealed almost the same results. However, in a study in Pakistan, Sharif et al. ${ }^{(1)}$ found that $34 \%$ of clinical details were completely absent.

In terms of turnover time, two studies have demonstrated that physicians were least satisfied and assigned the lowest scores to the turnover time in general, regardless of the test or the set (inpatient or outpatient). ${ }^{(3,8)}$

Regarding discrepancies and errors, all histopathology units should engage in quality management. However, no studies on errors or how to overcome them have been published in Saudi Arabia.

Multiple studies have revealed that errors were mostly due to failure of communication. ${ }^{(4,12)}$ Moreover, the error rate was not high in one of these studies, the mean was $6.7 \%$, of which $5.3 \%$ had a moderate or marked effect on patient care. ${ }^{(12)}$ Nonetheless, this does not neglect the importance of assessing a subjective view of these errors and establishing a further study to assess these errors objectively.

To the best of our knowledge, no study integrates the assessment of satisfaction between histopathologists and their clients, taking the opinions of both groups into consideration.

Our results indicate there is an overall propensity toward satisfactory results between both histopathologists and their clients in the three categories.

However, when compared to one of the earliest studies in the United States, which was to address the satisfaction of the clients, these results are lower, with scores of 4.31 , and $4.64^{(4)}$ in terms of turnover time and style of report.

It is worth noting that $47.3 \%$ of the clients were unsure about the turnover time required to sign off a report. A guideline or a notification from the system that provides the approximate turnover time once an order is placed could increase clients' satisfaction regarding this.

In addition, we must address the limitations of our study. The number of histopathologists was not large, although the results were relatively similar when compared to those of their clients. We could not address the rate of discrepancies due to the unsatisfactory response rate. We did not involve all the centers and laboratories that are certified by the College of American Pathologists and we only focused on histopathology units in the three major regions in Saudi Arabia.

Further studies should focus specifically on the discrepancies and errors, and fully examine both the reports from pathologists in general and the orders requested by their clients. Moreover, it would be interesting to compare the rate of satisfaction between other hospitals and units that are not certified by the College of American Pathologists and our results.

Finally, it is clear from these results that there is always a room for further improvement, and that it is possible to achieve this by adapting a continuous, standardized assessment.

\section{References}

1. Sharif, M., Mushtaq, S. and Mamoon, N. (2007). Clinician's Responsibility in Pre-Analytical Quality Assurance of Histopathology. Available at:

http://www.pjms.com.pk/issues/octdec107/article/article14.html

2. Shorrock, K. (1993). Use of histopathology services by general practitioners: recent changes in referral practice. Journal of Clinical Pathology, 46(11), pp.989-992.

3. Nakhleh, R. (2003). Physician Satisfaction With Surgical Pathology Reports: A 2-Year College of American Pathologists Q-Tracks Study. Archives of Pathology \& Laboratory Medicine Online. d.o.i.: 10.1043/1543-2165-132.11.1719

4. Sutcliffe, K., Lewton, E. and Rosenthal, M. (2004). Communication Failures: An Insidious Contributor to Medical Mishaps. Academic Medicine, 79(2), pp.186-194. 
5. Nakhleh, R., Souers, R., Bashleben, C., Talbert, M., Karcher, D., Meier, F. and Howanitz, P. (2014). Fifteen Years' Experience of a College of American Pathologists Program for Continuous Monitoring and Improvement. Archives of Pathology \& Laboratory Medicine, 138(9), pp.11501155 .

6. Tworek, J., Volmar, K., McCall, S., Bashleben, C. and Howanitz, P. (2014). Q-Probes Studies in Anatomic Pathology: Quality Improvement Through Targeted Benchmarking. Archives of Pathology \& Laboratory Medicine, 138(9), pp.1156-1166.

7. Meier, F., Souers, R., Howanitz, P., Tworek, J., Perrotta, P., Nakhleh, R., Karcher, D., Bashleben, C., Darcy, T., Schifman, R. and Jones, B. (2015). Seven Q-Tracks Monitors of Laboratory Quality Drive General Performance Improvement: Experience From the College of American Pathologists QTracks Program 1999-2011. Archives of Pathology \& Laboratory Medicine, 139(6), pp.762-775.

8. McCall, S., Souers, R., Blond, B. and Massie, L. (2016). Physician Satisfaction With Clinical Laboratory Services: A College of American Pathologists Q-Probes Study of 81 Institutions. Archives of Pathology \& Laboratory Medicine, 140(10), pp.1098-1103.

9. Nakhleh, R. (1996). Surgical pathology specimen identification and accessioning: A College of American Pathologists Q-Probes Study of 1004115 cases from 417 institut... - PubMed - NCBI. Ncbi.nlm.nih.gov. Available at: https://www.ncbi.nlm.nih.gov/pubmed/8629896

10. Burton, J. and Stephenson, T. (2001). Are clinicians failing to supply adequate information when requesting a histopathological investigation?. Journal of Clinical Pathology, 54(10), pp.806-808.

11. Nakhleh, R. (2011). Quality in Surgical Pathology Communication and Reporting. Archives of Pathology \& Laboratory Medicine, 135(11), pp.1394-1397.

12. Raab, S. (2006). Patient Safety in Anatomic Pathology: Measuring Discrepancy Frequencies and Causes. Yearbook of Pathology and Laboratory Medicine, 2006, pp.13-1

\section{Appendix}

Assessing Communication and Report Quality among Histopathologists and Their Clients.

\section{Histopathologists' Form}

\section{Name of Principle Investigator:}

Name of Institution: King Khalid University Hospital in Riyadh.

\section{Contact No.:}

Dear participant,

I would like to ask this opportunity if you are willing to take part of this questionnaire-based survey. For the research entitled "Assessing Communication and Report Quality among Histopathologists and Their Clients. Please answer the questions to the best of your knowledge. All information asked in this study questionnaire will be treated confidential. If you are willing to participate voluntarily in this study, please sign this form or agree verbally and you will be given a copy for your own records.

By filling this questionnaire, you agreed to take a part in this research.

Name (Optional):

Contact (Optional): 
Assessing Turnover, Communication and Report Quality

Assessing Communication and Report Quality Among Histopathologists and Their Clients.

Principle Investigator:

\begin{tabular}{|c|c|c|c|c|c|}
\hline \multicolumn{6}{|l|}{ Timing } \\
\hline Routine test turnover time & 5 & 4 & 3 & 2 & 1 \\
\hline Esoteric (rare) test turnover time & 5 & 4 & 3 & 2 & 1 \\
\hline Inpatient STAT (immediate) test turnover time & 5 & 4 & 3 & 2 & 1 \\
\hline outpatient STAT (immediate) test turnover time & 5 & 4 & 3 & 2 & 1 \\
\hline What is your saying about the timeliness? & 5 & 4 & 3 & 2 & 1 \\
\hline \multicolumn{6}{|l|}{ Communication } \\
\hline Critical value notification & 5 & 4 & 3 & 2 & 1 \\
\hline Accessibility to the physician & 5 & 4 & 3 & 2 & 1 \\
\hline Accessibility to the lab manager & 5 & 4 & 3 & 2 & 1 \\
\hline Accessibility to the lab staff & 5 & 4 & 3 & 2 & 1 \\
\hline Laboratory management responsiveness & 5 & 4 & 3 & 2 & 1 \\
\hline Intraoperative consultation & 5 & 4 & 3 & 2 & 1 \\
\hline \multicolumn{6}{|l|}{ Satisfaction about the report quality } \\
\hline Typographical errors? & 5 & 4 & 3 & 2 & 1 \\
\hline The accuracy and the reliability of the diagnosis? & 5 & 4 & 3 & 2 & 1 \\
\hline The sufficiency of the report content? & 5 & 4 & 3 & 2 & 1 \\
\hline Understandability of the report? & 5 & 4 & 3 & 2 & 1 \\
\hline The style of the report. & 5 & 4 & 3 & 2 & 1 \\
\hline Overall satisfaction? & 5 & 4 & 3 & 2 & 1 \\
\hline
\end{tabular}

Histopathologists satisfaction about their unit and communication with clinicians $(5=$ Most Satisfied, 1 = Least Satisfied)

Assessing Communication and Report Quality Among Histopathologists and Their Clients.

Principle Investigator:

\section{Discrepancies and Errors}

\begin{tabular}{|l|l|l|l|l|}
\hline How frequent are the discrepancies or errors you have & $<1$ & $1-4$ & $5-10$ & $>10$ \\
encountered from the histopathology unit in past year? & & & & \\
\hline $\begin{array}{l}\text { In your opinion, how often do these errors result in harm } \\
\text { (significant event) to the patient's care? }\end{array}$ & $<1$ & $1-4$ & $5-10$ & $>10$ \\
\hline $\begin{array}{l}\text { In your opinion, how often do these errors result in a near miss } \\
\text { event? }\end{array}$ & $<1$ & $1-4$ & $5-10$ & $>10$ \\
\hline $\begin{array}{l}\text { In your opinion, how often do these errors result in a no harm } \\
\text { event? }\end{array}$ & $<1$ & $1-4$ & $5-10$ & $>10$ \\
\hline
\end{tabular}

In case of asking for a second review for the report, the usual cause is:

- The diagnosis doesn't correlate with the clinical presentation.

- Insufficient details.

- Non-understandable (lack of clarity) report.

- Misidentification of the patient. 


\section{Expectations:}

Is the number of the employees in histopathology unit adequate to fulfill or meet the requirements of hospital?

- Yes

- Somehow

- No

Are the unit technicians sufficiently trained to perform what is required when needed?

- Yes

- Somehow

- No

Assessing Communication and Report Quality Among Histopathologists and Their Clients.

\section{Clients' Form}

\section{Name of Principle Investigator:}

Name of Institution: King Khalid University Hospital in Riyadh.

Contact No.:

Dear participant,

I would like to ask this opportunity if you are willing to take part of this questionnaire-based survey. Please answer the questions to the best of your knowledge. All information asked in this study questionnaire will be treated confidential. If you are willing to participate voluntarily in this study, please sign this form or agree verbally and you will be given a copy for your own records.

I agree to participate in this study survey, and to utilize the information for scientific research purposes

Name (Optional):

Contact (Optional):

Department:

Assessing Communication and Report Quality Among Histopathologists and Their Clients.

Principle Investigator:

Physicians Satisfaction About Histopathology Unit Quality (5 = Most Satisfied, 1 = Least Satisfied)

\begin{tabular}{|c|c|c|c|c|c|}
\hline \multicolumn{6}{|l|}{ Timing } \\
\hline Routine test turnover time & 5 & 4 & 3 & 2 & 1 \\
\hline Esoteric test turnover time & 5 & 4 & 3 & 2 & 1 \\
\hline Inpatient STAT (immediate) test turnover time & 5 & 4 & 3 & 2 & 1 \\
\hline outpatient STAT (immediate) test turnover time & 5 & 4 & 3 & 2 & 1 \\
\hline What is your saying about the timeliness? & 5 & 4 & 3 & 2 & 1 \\
\hline \multicolumn{6}{|l|}{ Communication } \\
\hline Critical value notification & 5 & 4 & 3 & 2 & 1 \\
\hline Accessibility to the pathologist & 5 & 4 & 3 & 2 & 1 \\
\hline Accessibility to the lab manager & 5 & 4 & 3 & 2 & 1 \\
\hline Accessibility to the lab staff & 5 & 4 & 3 & 2 & 1 \\
\hline Laboratory management responsiveness & 5 & 4 & 3 & 2 & 1 \\
\hline Intraoperative consultation & 5 & 4 & 3 & 2 & 1 \\
\hline
\end{tabular}




\begin{tabular}{|l|l|l|l|l|l|}
\hline Typographical errors? & 5 & 4 & 3 & 2 & 1 \\
\hline The accuracy and the reliability of the diagnosis? & 5 & 4 & 3 & 2 & 1 \\
\hline The sufficiency of the report content? & 5 & 4 & 3 & 2 & 1 \\
\hline Understandability of the report? & 5 & 4 & 3 & 2 & 1 \\
\hline The style of the report. & 5 & 4 & 3 & 2 & 1 \\
\hline Overall satisfaction? & 5 & 4 & 3 & 2 & 1 \\
\hline
\end{tabular}

Assessing Communication and Report Quality Among Histopathologists and Their Clients.

\begin{tabular}{|l|l|l|l|l|}
\hline Discrepancies and Errors & & & \\
\hline $\begin{array}{l}\text { How frequent are the discrepancies or errors you have } \\
\text { encountered from the histopathology unit in past year? }\end{array}$ & $<1$ & $1-4$ & $5-10$ & $>10$ \\
\hline $\begin{array}{l}\text { In your opinion, how often do these errors result in harm } \\
\text { (significant event) to the patient's care? }\end{array}$ & $<1$ & $1-4$ & $5-10$ & $>10$ \\
\hline $\begin{array}{l}\text { In your opinion, how often do these errors result in a near miss } \\
\text { event? }\end{array}$ & $<1$ & $1-4$ & $5-10$ & $>10$ \\
\hline $\begin{array}{l}\text { In your opinion, how often do these errors result in a no harm } \\
\text { event? }\end{array}$ & $<1$ & $1-4$ & $5-10$ & $>10$ \\
\hline
\end{tabular}

\section{Principle Investigator:}

In case of asking for a second review for the report, the usual cause is:

- The diagnosis doesn't correlate with the clinical presentation.

- Insufficient details.

- Non-understandable (lack of clarity) report.

- Misidentification of the patient.

\section{Expectations:}

Are you familiar with the process immediately after ordering the test?

- Yes

- Somehow

- $\mathrm{No}$

Are you familiar with time required (based on your hospital standards) to deliver the final report about the specimen -whether it was routine, or urgent- immediately after ordering the test?

- Yes

- Somehow

- $\mathrm{No}$

- Defining Variables:

○ Turnover time: Turning inputs (orders for tests, patient identifiers and specimens) into outputs (reporting events, potentially critical values) in a relevant time.

Esoteric test: The analysis of rare cases that are not usually done in the lab.

O Discrepancy: A discrepancy has occurred if there is any difference between the original interpretation and the interpretation after the second review. 
- Near miss events: A discrepancy that was detected before harm occurred, such as a discrepancy that was discrepancy that was detected at tumor meeting board before treatment was initiated.

○ No harm events: A discrepancy that did not result in patient harm, such as typographic errors that had no bearing on patient management.

- Harm event: A discrepancy that resulted in patient harm (e.g. false treatment, death, loss of organ, psychological events).

\section{Acknowledgement:}

Special thanks to:

Prof. Maha Arafah, a consultant histopathologist and the director of histopathology lab quality unit in King Khalid University Hospital for her help in reviewing the questionnaire.

And to the data collectors:
1) Fay Saad AlRuwais.
2) Rabab Hussain AlNazar.
3) Manar Mutlag AlHarthi.
4) Hotoun Fayez Bokhari.
5) Naif Mohammed Al-Ahmadi.

Disclosure: Authors have no conflict of interest, and the work was not supported or funded by any agency. This study was approved by the Deanship of Scientific Research, King Saud University, Riyadh, Kingdom of Saudi Arabia through Vice Deanship of Scientific Research Chairs. 